
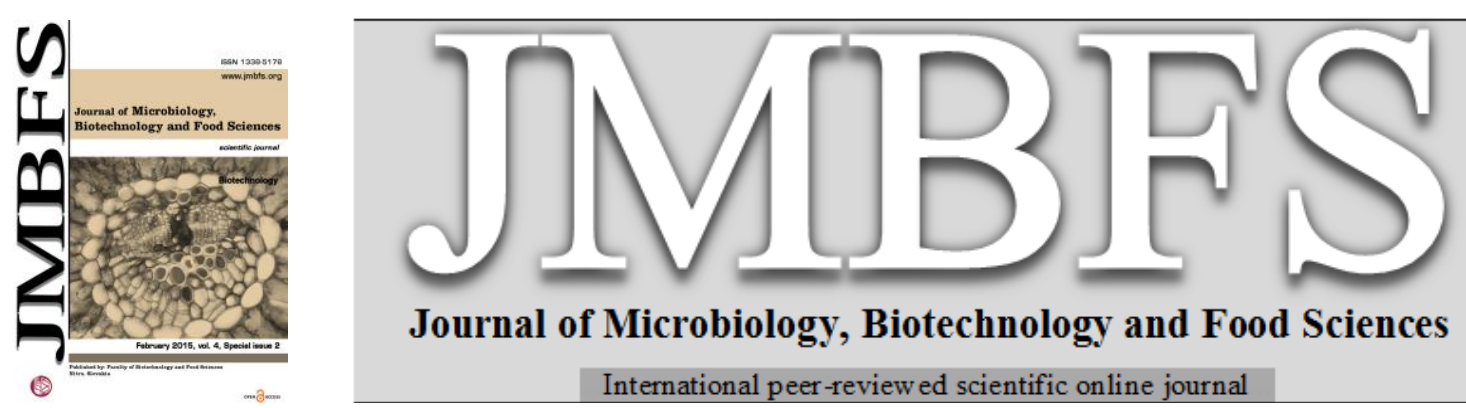

Journal of Microbiology, Biotechnology and Food Sciences

International peer-review ed scientific online journal

\title{
IMPACT OF 4-NONYLPHENOL ON TESTOSTERONE PRODUCTION IN MICE LEYDIG CELLS
}

\author{
Tomáš Jambor *I, Jana Lukáčová ${ }^{1}$, Eva Tvrdá ${ }^{1}$, Zuzana Kňažická ${ }^{1}$, Zsolt Forgács ${ }^{2}$, Norbert Lukáčl
}

Address(es): Ing. Tomáš Jambor, Slovak University of Agriculture, Faculty of Biotechnology and Food Sciences, Department of Animal Physiology, Trieda A. Hlinku 2, 94976 Nitra, Slovak Republic, phone number: +421-37-6414288.

${ }^{1}$ Slovak University of Agriculture, Faculty of Biotechnology and Food Sciences, Department of Animal Physiology, Trieda A. Hlinku 2, 94976 Nitra, Slovak Republic, phone number: +421-37-6414288.

${ }^{2}$ National Institute of Chemical Safety, Nagyvárad tér 2, H-1450, Budapešt', Hungary, phone number: 06-1-476-1180.

*Corresponding author: tomasjambor1@gmail.com

doi: $10.15414 / j m b f s .2015 .4 . s p e c i a l 2.42-44$

\section{ARTICLE INFO}

Received 19.11.2014

Revised 10. 12. 2014

Accepted 19. 1.2015

Published 2. 2. 2015

Regular article

OPEN ACCESS

\begin{abstract}
Nonylphenol (NP) is an important environmental toxicant and potential endocrine disrupting chemical. It is also the primary final biodegradation product of nonylphenol polyethoxylate, a non-ionic surfactant that is frequently incorporated into detergent formulation. Several studies have reported adverse effects of NP on the male reproductive system, including hormonal changes and testicular abnormalities. However, its mechanisms are not clearly understood. In the present study, experiments were performed to examine the effects of 4-nonylphenol on the testosterone production in mice Leydig cells. Interstitial (Leydig) cells were cultured with addition of $0.04,0.2,1.0,2.5$ and $5 \mu \mathrm{g} / \mathrm{mL}$ of 4-nonylphenol and compared with control. Concentrations of testosterone in the media were determined using enzyme linked immunosorbent assay (ELISA). Hormone production significantly $(P<0.05)$ increased at 1.0, 2.5 and $5.0 \mu \mathrm{g} / \mathrm{mL}$ of 4-nonylphenol concentrations. Results of the study indicated dose-dependent increases in testosterone production of interstitial (Leydig) cells following a $48 \mathrm{~h}$ in vitro 4-nonylphenol exposure. Further investigations are required to establish the biological significance and possible reproductive implications.
\end{abstract}

Keywords: Leydig cells, nonylphenol, testosterone, ELISA

\section{INTRODUCTION}

A number of man-made chemical compounds, often referred to as xenobiotics have been shown to have hormone-like activity. These hormone-like compounds are also referred as environmental endocrine disrupters. Endocrine-disrupting chemicals interfere with the synthesis, metabolism, or action of hormones. Continuous exposure of these types of compounds induces problems in humans and animals health (Nimrod and Benson, 1996).

Alkylphenols are potential endocrine-disrupting chemicals widely used as plastic additives and surfactants. Alkylphenol ethoxylate (APEO), consisting of approximately $80 \%$ nonylphenol ethoxylate (NPEO), has been proven as an endocrine disruptor. Nonylphenol ethoxylates are nonionic surfactants found in plastics, latex, and paints. The primary degradation product of NPEO is nonylphenol (NP). Actually, NP consists mainly of a mixture of para-subsituted mono-alkylphenols with various isomeric nonyl groups. The theoretical number of possible NP isomers is 211 (Hawrelak, et al., 1999). NP is one of the most abundant APEO derivatives and has been shown to stay biologically active for a longer period of time in the body that endogenous estrogens (Tapiero et al., 2002).

NP has been found in polyvinyl chloride, which is used in the food processing and packing industries and may contaminate water flowing through polyvinyl chloride pipes. NP has also been detected in food products, marmalade, butter, tomatoes. Many studies have classified NP as hazardous to the health of human and animals, especially to male reproduction (Junk et al., 1974). In the exposure of NP on the male reproductive system was observed reduced reproductive organ weights, decreased sperm production and testicular abnormalities. Since these endpoints are sensitive to hormone levels, particularly the level of testosterone. However, its mechanisms are not fully understood (Lee et al., 1999).

Testis is the target organ for most male reproductive toxicants. Leydig cells are located in the testicular interstitium. They are situated between seminiferous tubules in testis and they have spherical shape. They are an important part development of male reproductive organs and male reproduction (Habert and Picon, 1982).

The main function of Leydig cells is androgen production especially testosterone (male sex hormone). This hormone is responsible for the maintenance of spermatogenesis and secondary sexual characteristics in the male. During steroidogenesis, the substrate cholesterol is converted to testosterone through a series of steroidogenic steps catalyzed by different proteins, including the enzymes StAR, P450 $0_{\mathrm{SCC}}$, 3 $\beta$-HSD, P450 $0_{\mathrm{c} 17}$ and $17 \beta$-HSD. Reduction in activities of these steroidogenic protein directly reduces testosterone synthesis in Leydig cells (Payne and Hales, 2004). The biosynthesis of steroid hormones by Leydig cells requires the sequential actions that convert cholesterol into various steroid classes (Figure 1).

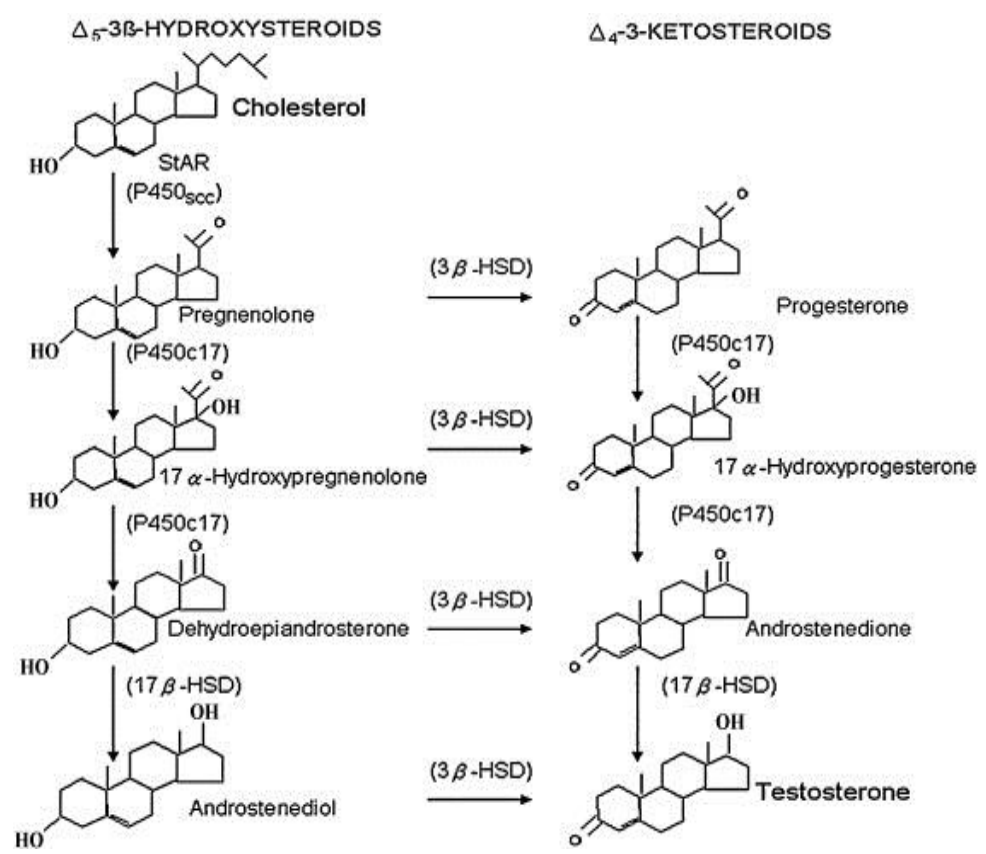

Fig.1. Schematic representation of the steroidogenic pathway of testosterone (Wu et al., 2010). 
Nonylphenol at concentration as low as $0,1 \mu \mathrm{g} / \mathrm{L}$ evokes a public health risk. Several studies have describes effects of NP on steroidogenesis of Leydig cells with an increase at low concentrations and a decrease at high concentrations. The intratesticular mechanism by which NP modulates steroidogenesis has not been well defined but it can be partially explained by the activation or inhibition of the enzymes required for the biosynthesis of testosterone in Leydig cells, including CYP11A1, 3 $\beta$-HSD and 17 $\beta$-HSD (Laurenzana et al., 2002; Payne and Sha, 1991)

In the present study interstitial (Leydig) cells were isolated from testes of male mice. Qualified isolation of these cells is very important for primary culture, which lays the foundation for and play a key role in all research in this field. We used interstitial (Leydig) cells as an in vitro model system for detection toxic effects of 4-nonylphenol at various concentrations on the steroid hormones production.

\section{MATERIAL AND METHODS}

\section{Interstitial cell preparation and incubation}

Interstitial cells were prepared and cultured from testicles of the male mice These cells were isolated by mechanical dissociation without enzyme treatment as previously described be Stoklosowa (1982), with slight modification. In brief, decapsulated testicles were placed on a nylon sieve over a beaker. Then, with the help of a $10 \mathrm{~mL}$ syringe and needle (Luer 22G), interstitial cells were rinsed out with a vigorous stream of minimum essential medium (MEM, live technologies, Bratislava, Slovak Republic) without serum and collected in a beaker placed on ice, underneath the sieve. After centrifugation $\left(300 \mathrm{x} \mathrm{g}, 4^{\circ} \mathrm{C}, 10 \mathrm{~min}\right)$ the cells were washed twice, resuspended, and diluted to $10^{6}$ cells $/ \mathrm{mL}$ in the culture medium (MEM) supplemented with $10 \%$ fetal bovine serum (FBS; BiochromAG, Berlin, Germany), $100 \mathrm{IU} / \mathrm{mL}$ penicillin, and $100 \mu \mathrm{g} / \mathrm{mL}$ streptomycin (SigmaAldrich, Bratislava, Slovak Republic).The cell suspension was plated (with final volume of $500 \mu \mathrm{L} /$ well) into sterile 24-well plates (Nunclon, Denmark) Interstitial cells were treated for $48 \mathrm{~h}$ in MEM medium that contained differen concentration of 4-nonylphenol (4-n-NP; Fluka, Buchs, Switzerland), 0.04; 0.2 $1 ; 2.5 ; 5 \mu \mathrm{g} / \mathrm{mL}$. All incubations were carried out at $34^{\circ} \mathrm{C}$ under a humidified atmosphere of $95 \%$ air and $5 \% \mathrm{CO}_{2}$. After respective cell treatments, culture media were removed and frozen at $-20^{\circ} \mathrm{C}$ until testosterone determination.

\section{Quantification of testosterone}

After $48 \mathrm{~h}$ of 4-nonylphenol exposure, cell culture medium was collected from al the wells and centrifuged in eppendorf tubes. After centrifugation the supernatant was stored at $-20^{\circ} \mathrm{C}$. Determination of testosterone was performed by enzyme linked immunosorbent assay (ELISA). The ELISA kits were used for quantitative determination steroid hormones. These kits were purchased from Dialab (testosterone Cat. \# K00234, Austria). The samples were measured at wavelength $450 \mathrm{~nm}$.

\section{Statistical Analysis}

Obtained data were statistically analyzed using GraphPad Prism 3.02 (GraphPad Software Incorporated, San Diego, California, USA). Descriptive statistical characteristics (minimum, maximum mean etc.) were evaluated. One way analysis of variance (ANOVA) and the Dunnett's multiple comparison test were used for statistical evaluations. The level of significance was set at $* * *(P<0.001)$ $* *(P<0.01)$ and $*(P<0.05)$

\section{RESULTS AND DISCUSSION}

The interstitial (Leydig) cells were exposed to five different concentrations of 4 nonylphenol for $48 \mathrm{~h}$. Various concentrations of 4-nonylphenol showed a possible impact on the testosterone production. Our data show increased testosterone production in whole applied concentration range. Testosterone production was significantly $(P<0.05)$ increased at the $1.0 \mu \mathrm{g} / \mathrm{mL}$ concentration of 4-nonylphenol. Hormone production also significantly $(P<0.05)$ increased at higher concentration $(2.5$ and $5.0 \mu \mathrm{g} / \mathrm{mL})$. Results of the study indicated dosedependent increases in testosterone production of interstitial (Leydig) cells following a $48 \mathrm{~h}$ in vitro 4-nonylphenol exposure. Results are shown in the figure 2 .
Effect of 4-nonylphenol on the basal testosterone production of mouse Leydig cells

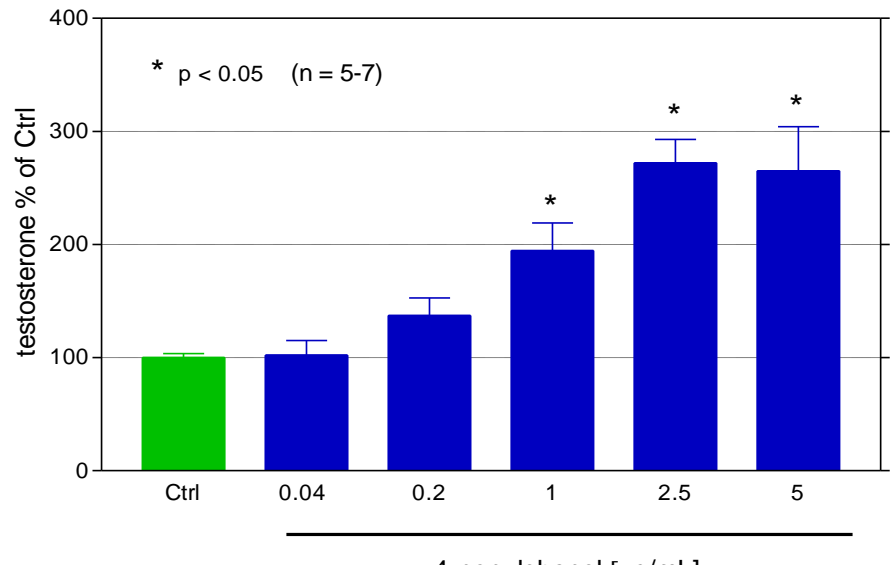

4-nonylphenol $[\mu \mathrm{g} / \mathrm{mL}]$

Figure 2 Effect of increasing concentrations of 4-nonylphenol on the testosterone production of $48 \mathrm{~h}$.

Legend: Ctrl - Control, Each bar represents the mean ( \pm SEM) testosterone \% of (untreated) control. The number of replicate wells was 5-7 at each point per experiment. The statistical difference between the values of control and treated cells in indicated by asterisks $* P<0.05$ (One-way ANOVA with Dunnett's multiple comparison test).

Endocrine-disrupting chemicals (EDCs) are widely dispersed in the environment and are persistent organic pollutants. Previous studies showed that EDCs exhibited potential hazardous effect on animal reproduction and development and on reproductive function in male (Carlsen et al., 1992). In recent years, there has been increased interest in assessing the relationship between impaired male fertility and environmental factors. Studies have demonstrated that nonylphenol, one of the most common EDCs, could result in reproductive problems (Soares $\boldsymbol{e}$ al., 2008). Previous studies were usually performed using commercial nonylphenol, which is a mixture of many isomers. Kim et al. (2004) first separated eight fractions from commercial nonylphenol by high performance liquid chromatography (HPLC) and studied their different effects. His next study demonstrated that nonylphenol isomers had differential effects on the release of testosterone in Leydig cells.

The results of our study indicate dose-dependent increase in testosterone production of interstitial mice (Leydig) cells following in vitro 4-nonylpheno treatment after $48 \mathrm{~h}$ of cultivation. Testosterone production was significantly $(P<0.05)$ increased at $1.0 ; 2.5$ and $5.0 \mu \mathrm{g} / \mathrm{mL}$ concentrations of 4-nonylphenol.

Morphologic changes of Leydig cells were detected, with decreased cell density at high doses of 4-nonylphenol. In case of testosterone the hormone was increased at lower concentrations of 4-nonylphenol while decreased at high concentrations of nonylphenol (Ying $\boldsymbol{e t}$ al., 2006). The testosterone biosynthesis by Leydig cells requires the sequential actions that convert cholesterol into various steroid classes during which $3 \beta-\mathrm{HSD}, \mathrm{CYP} 11 \mathrm{~A} 1$ and StAR are responsible for the rate-limiting step (LaVoie and King, 2009). Objective of nex study was assess the adverse effects of nonylphenol on the reproductive function of adult male rats. In vitro study of testicular cells from adult male rats by use of culture solution with different nonylphoneol concentrations was conducted. Testosterone production in cell culture medium was examined and the ultrastructure of Leydig cells was observed under electron microscope. Study showed that testosterone secretion was inhibited at higher doses and electron microscopy disclosed that the endoplasmic reticulum of Leydig cell swells, which might indicate the reduction of testosterone biosynthesis (Zhang $\boldsymbol{e t}$ al., 2003). Close attention has been paid to the alterations on the normal functioning of the endocrine system by EDCs and thereby adverse reproductive consequences, including a decline in reproductive capability (Carlsen $\boldsymbol{e t} \boldsymbol{a l}$. 1992).

\section{CONCLUSION}

The action of endocrine disrupting chemicals on Leydig cell function and the reproductive potential is a complex process that depends on the dose, the developmental stage of the exposed target organism and many other factors. Some authors investigated the toxic effects of nonylphenol on various types of cells. In our study, we found that the 4-nonylphenol showed effect on mice interstitial (Leydig) cells. We may conclude that some experimental concentrations of 4-nonylphenol significantly increased the testosterone production of these cells after $48 \mathrm{~h}$ of cultivation. Further investigations are required to establish the biological significance and possible reproductive implications. 
Acknowledgments: This study was supported by the European Community under the Project no. 26220220180: Building Research Centre „AgroBioTech" and the Scientific Grant Agency of the Ministry of Education of the Slovak Republic VEGA, Project no. 1/0857/14.

\section{REFERENCES}

CARLSEN, E., GIWERCMAN, A., KEIDING, N., SKAKKEBAEK, N.E. 1992. Evidence for decreasing quality of semen during past 50 years. British Medical Journal, 305, 609-613.

HABERT, R., PICON,R. 1982. Control of testicular steroidogenesis in fetal effect of decapitation on testosterone and plasma luteinizing hormone - like activity. Acta Endocrinologica, 99(3), 466-473.

HAWRELAK, M., BENNETT, E., METCALFE, C. 1999. The environmenta fate of the primary degradation products of alkylphenol ethoxlate surfactants in recycled paper sludge. Chemosphere, 39(5), 754-752. http://dx.doi.org/10.1016/S0045-6535(99)00010-7.

JUNK, G.A., SVEC, H.J., VICK, R.D., AVERY, M.J. 1974. Contamination of water by synthetic polymer tubes. Environmental Science and Technology, 8, 1100-1106. http://dx.doi.org/10.1021/es60098a009.

KIM, Y.S., KATASE, T., SEKINE, S., INOUE, T., MAKINO, M., UCHIYAMA, T., FUJIMOTO, Y., YAMASHITA, N. 2004. Variation in estrogenic activity among fractions of a commercial nonylphenol by high performance liquid chromatography. Chemosphere, 54, 1127-1134 http://dx.doi.org/10.1016/j.chemosphere.2003.09.024.

LAURENZA, E.M., BALASUBRAMANIAN, G., WEIS, C., BLAYDES, B., NEWBOLD, R.R., DELCLOS, K.B. 2002. Effect of nonylphenol on serum testosterone levels and testicular steroidogenic enzyme activity in neonatal, pubertal, and adult rats. Chemico-Biological interactions, 139(1), 23-41. http://dx.doi.org/10.1016/S0009-2797(01)00291-5.

LAVOIE, H.A., KING, S.R. 2009. Transcriptional regulation of steroidogenic genes: STARD1, CYP11A1 and HSD3B. Experimental Biology and Medicine, 234, 880-907.

LEE, P.C., ARNDT, P., NICKELS, K.C. 1999. Testicular abnormalities in male rats after lactational exposure to nonylphenols. Endocrine, 11, 61-68.

NIMROD, A.C., BENSON, W.H. 1996. Environmental estrogenic effects of alkylphenoletoxylates. Critical Reviews in Toxicology, 26, 335-364. http://dx.doi.org/10.3109/10408449609012527.

PAYNE, A.H., HALES, D.B. 2004. Overview of steroidogenic enzymes in the pathway from cholesterol to active steroid hormones. Endocrine Reviews, 25, 947-970. http://dx.doi.org/10.1210/er.2003-0030.

PAYNE, A.H., SHA, L. 1991. Multiple mechanisms for regulation of $3 \beta$ hydroxysteroid dehydogenase $/ \Delta^{5} \rightarrow \Delta^{4}$-Isomerase, $17 \alpha$-Hydroxylase/ $\mathrm{C}_{17-20}$ Lyase Cytochrome P450, and Cholesterol Side-Chain Cleavage Cytochrome P450 Messenger Ribonucleic Acid Levels in Primary Cultures of Mouse Leydig Cells. Endocrinology, 129(3), 1429-1435. http://dx.doi.org/10.3390/ijms140917926.

SOARES, A., GUIEYSSE, B., JEFFERSON, B., CARTMELL, E., LESTER, J.

2008. Nonylphenol in the environment: a critical review on occurrence, fate, toxicity and treatment in wastewaters. Environmental International, 34, 1033 1049. http://dx.doi.org/10.1016/j.envint.2008.01.004.

STOKLOSOWA, S. 1982. Tissue culture of gonadal cells. Acta Biologica Academiae Scientiarum Hungaricae, 33(4), 367-379.

TAPIERO, H., NGUYEN, B.G., TEW, K.D. 2002. Estrogens and environmental estrogens. Biomedical Pharmacother, 56, 36-44.

WU, J.J., WANG, K.L., WANG, S.W., HWANG, G.S., MAO, I.F., CHEN, M.L., WANG, P.S. 2010. Differential effects of nonylphenol on testosterone secretion in rat Leydig cells. Toxicology, 268, 1-7. http://dx.doi.org/10.1016/j.tox.2009.10.030

YING, F., GONG, Y., HAN, X.D. 2006. Effect of nonylphenol on testosterone secretion of rat leydig cells in vitro. National Journal of Andrology, 4, 300-307.

ZHANG, H., ZENG, X., CHENG, W., WU, D. 2003. Adverse effects of nonylphenol on the reproductive function of adult male SD rats. Journal of Sichuan University. Medical science edition, 34(2), 295-297. 